\title{
Extensional and compressional faults in the Everest-Lhotse massif, Khumbu Himalaya, Nepal
}

\author{
M. P. SEARLE \\ Department of Earth Sciences, Oxford University, Parks Road, Oxford OX1 3PR, UK \\ (e-mail:mike.searle@earth.ox.ac.uk)
}

\begin{abstract}
Two large-scale north-dipping, low-angle normal faults cut the Everest massif at the top of the High Himalayan slab in Nepal. The upper fault the Qomolangma Detachment, follows the north slope of Everest from above the 'Yellow Band' at $c .8500 \mathrm{~m}$ on the Southwest Face down to the Rongbuk glacier. On the south side of Everest this fault places unmetamorphosed Ordovician mudstones and limestones above biotite-grade marbles, calc-silicates and greenschists (Everest series pelites). The lower normal fault, the Lhotse Detachment, places greenschist grade calc-silicates and pelites above sillimanite-K-feldspargrade gneisses (quartz+ biotite + garnet $+\mathrm{K}$-feldspar + plagioclase + sillimanite \pm cordierite assemblages) formed at temperatures above $650^{\circ} \mathrm{C}$. Abundant sheet intrusions, sills and dykes of leucogranite containing tourmaline + muscovite \pm biotite \pm garnet are restricted to the footwall of the Lhotse Detachment. The mid-upper greenschist grade Everest pelites, some $2000 \mathrm{~m}$ thick on the SW face of Everest, form a northward tapering wedge bounded by normal faults below and above. A major compressional fault, the Khumbu Thrust, bounds the base of a $c .3-6 \mathrm{~km}$ thick sheet which consists of a series of flat-lying leucogranite sills or sheets extending more than $25 \mathrm{~km}$ south of Everest. The leucogranite peaks of Ama Dablam, Kangteiga and Tamserku are all part of the same sheet, which, prior to erosion, was probably originally continuous. The main granite emplacement mechanism was by syn-tectonic magma injection by hydraulic fracture propagation during simple shear, along a series of large sills from their source region at depth to the north. Granite emplacement occurred during upper crustal extension along the top of the High Himalayan slab, although final motion on the Lhotse Detachment post-dated granite emplacement. Both the normal faults at the top of the slab and the Khumbu thrust at the base of the leucogranite sheets were mechanically linked, resulting in the southward extrusion of rocks formed at c. $12-30 \mathrm{~km}$ depth within the High Himalayan slab.
\end{abstract}

Keywords: Everest, Himalaya, extension, compression, leucogranite.

The Himalaya have been under continuous north-south compression since the time of the India-Asia collision at c. 54 $50 \mathrm{Ma}$ (Molnar 1988; Searle et al. 1987). Crustal shortening and thickening processes resulted in Late Eocene to Early Miocene regional Barrovian-series metamorphism, culminating in a widespread phase of crustal melting along the High Himalaya during the early and mid-Miocene, mainly between 21 and $17 \mathrm{Ma}$ (Le Fort et al. 1987; Searle 1996). The High Himalayan slab is the north-dipping wedge of middle and deep crustal metamorphic rock, migmatites and leucogranites which coincide closely with the axis of highest topography (Fig. 1). The slab is bounded along the base (south) by the Main Central Thrust, a crustal-scale fault associated with characteristic inverted metamorphic isograds (Gansser 1964; Pêcher 1989; Hubbard 1989; Macfarlane et al. 1992) and along the top (north) by the South Tibetan Detachment system of orogenparallel normal faults which separate the metamorphic and anatectic core of the Himalaya from the Tethyan passive margin sedimentary sequence to the north (Burg 1983; Burg et al. 1984; Burchfiel et al. 1992; Hodges et al. 1993).

Structural studies and geochronology have revealed that thrusting and normal faulting are broadly synchronous (Hodges et al. 1992, 1998). Detailed mapping combined with $\mathrm{U}-\mathrm{Pb}$ geochronology in the Annapurna region, has shown that the detachment system is complex, with multiple episodes of extension and shortening across the slab (Hodges et al. 1996). Major out-of-sequence thrusts, such as the Modi Khola shear zone (Hodges et al. 1996) and the Kalopani shear zone
(Vannay \& Hodges 1996), have also been mapped within the metamorphic core in the Annapurna region. All of these faults clearly post-date peak metamorphism and melting, as shown by the inversion of earlier formed metamorphic isograds along the Main Central Thrust zone and the omission of parts of the section across the normal faults at the top of the slab. Structural and thermobarometric data from the Main Central Thrust zone south of Everest suggest that syn-metamorphic deformation at temperatures of $500-550^{\circ} \mathrm{C}$ was active at $20.9 \pm 0.2 \mathrm{Ma}$, the ${ }^{40} \mathrm{Ar} /{ }^{39} \mathrm{Ar}$ plateau age of hornblende growing along the thrust fabric (Hubbard \& Harrison 1989). In situ ${ }^{208} \mathrm{~Pb} /{ }^{232} \mathrm{Th}$ dating of monazite inclusions in garnet from west Nepal shows that peak metamorphic recrystallization of the Main Central Thrust footwall occurred at only c. $6 \mathrm{Ma}$ (Harrison et al. 1997a) suggesting that some late-stage reactivation occurred along the Main Central Thrust. Cooling ages as young as 9.7-2.3 Ma derived from ${ }^{40} \mathrm{Ar} /{ }^{39} \mathrm{Ar}$ dating of muscovites along the Main Central Thrust zone in Langtang also suggest late-stage reactivation along this thrust (Macfarlane 1993).

This paper examines the structure of the upper part of the High Himalayan slab in the Everest-Lhotse area on the Nepal side, where new mapping has revealed two large-scale, shallowangle normal faults, the upper Qomolangma Detachment and the lower Lhotse Detachment, both part of the South Tibetan Detachment system, and one newly identified thrust, the Khumbu Thrust, which carries a $3-6 \mathrm{~km}$ thick sheet of leucogranitic rocks and sillimanite-grade metamorphic rocks 


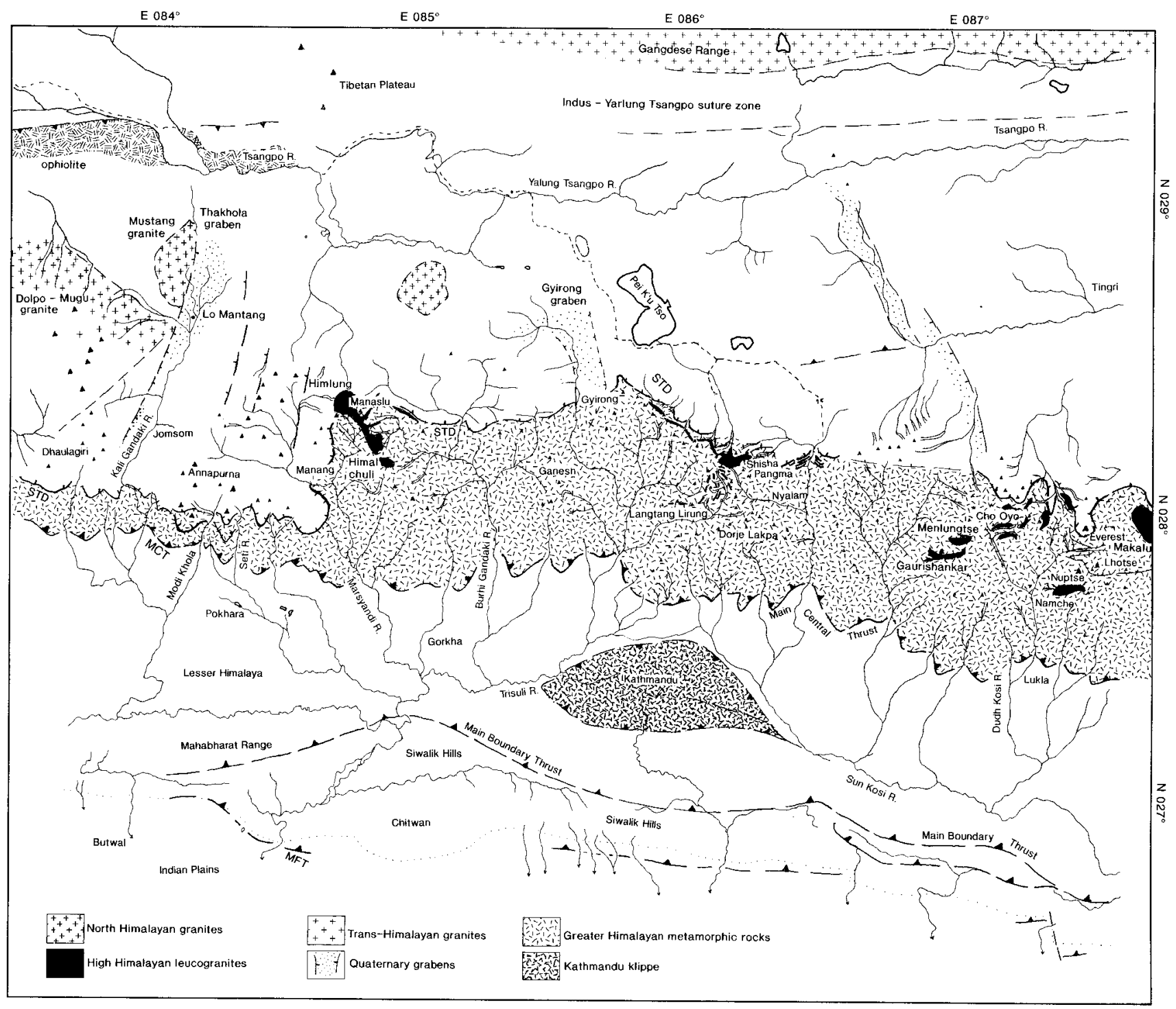

Fig. 1. Sketch map of the central Nepal Himalaya and South Tibet showing the extent of the High or Greater Himalayan slab (stippled), the High Himalayan leucogranites (black) and the North Himalayan granites (crosses). STD is the South Tibetan Detachment.

at least $25 \mathrm{~km}$ south of the Everest area (Figs 2 \& 3). Samples from the summit of Everest down to the South Col and the Base Camp site on the Khumbu glacier clearly reveal large jumps in metamorphic grade across the lower of the two major normal faults, the Lhotse Detachment. The faults and the leucogranite sheets have been mapped from the Everest area westwards to Cho Oyu and the Ngozumpa glacier, and they probably extend further west, to the Rolwaling, Shisha Pangma and Langtang Himalaya in central Nepal.

\section{Geology of Everest}

The earliest pioneering geological work on Everest was linked to mountaineering expeditions (Odell 1948; Lombard 1958; Wager 1965). Reconnaissance mapping of the Imja Khola south of Nuptse has been carried out by Polino (1981). More recent structural and metamorphic observations have been published by Brunel (1986) from the Arun valley, southeast of
Everest, and Hubbard (1989) from the Main Central Thrust zone south of Everest. The northern side of Everest along the Rongbuk glacier was mapped by Burchfiel et al. (1992) and Hodges et al. (1992) as part of their study of the South Tibetan Detachment system north of the Himalaya. They identified the Qomolangma Detachment separating largely unmetamorphosed sediments above from sillimanite-grade gneisses, migmatites and leucogranites below, and also discovered the Rongbuk granite pluton which apparently cross-cuts the Qomolangma Detachment, one of only two leucogranites (with Manaslu) which supposedly cut the fault anywhere along the Himalayan range.

Lombardo et al. (1993) and Pognante \& Benna (1993) studied the structure and metamorphism of a traverse from the Rongbuk glacier in the north to Makalu and the Arun valley in Nepal. Pognante \& Benna (1993, fig. 1) mapped only one normal fault, corresponding to the Qomolangma detachment, but Lombardo et al. (1993) identified two major 


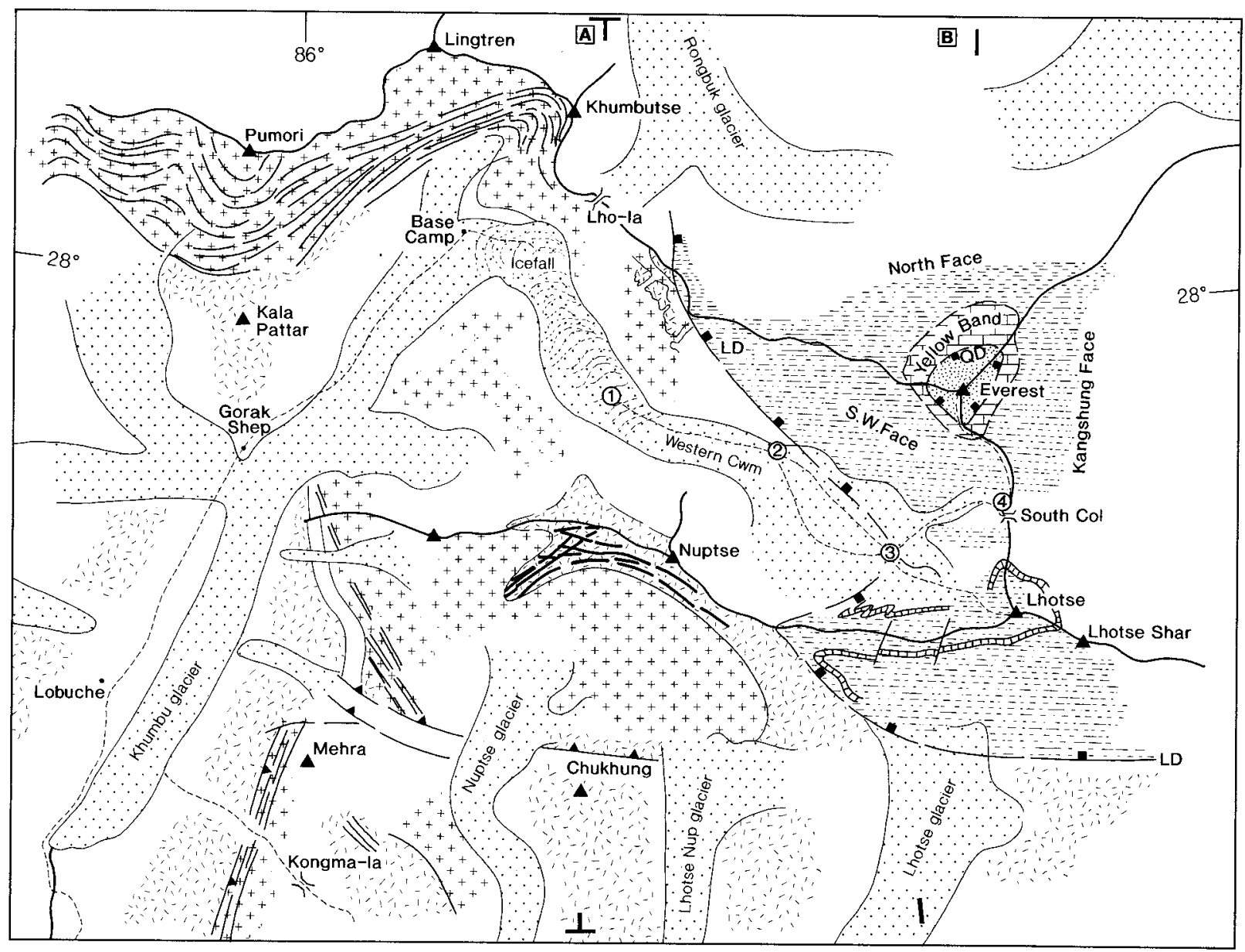

KEY
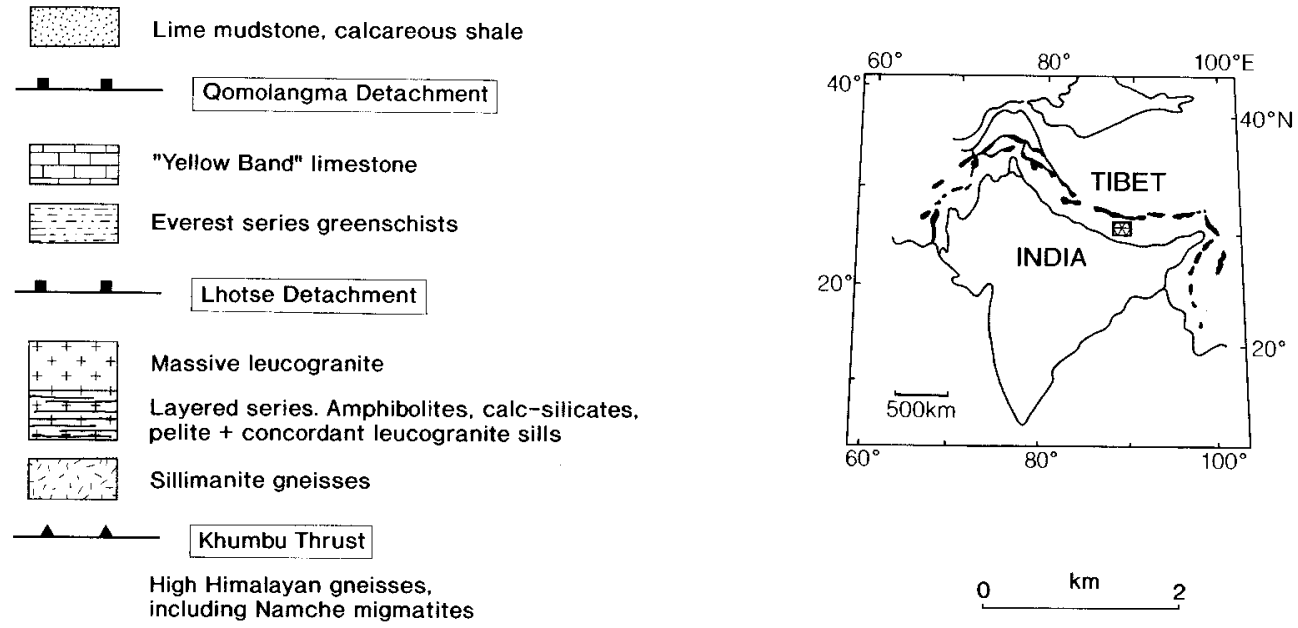

Fig. 2. Geological map of the Everest-Lhotse massif. The four camps marked are the sites on the standard South Col climbing route up Everest.

low-angle normal faults - the upper one separating Ordovician limestones from the 'North Col Formation' consisting of biotite schists and phyllites, epidote hornfels and calc-silicate rocks, and a lower fault separating these rocks from highgrade gneisses containing sillimanite, cordierite and staurolite of the 'Rongbuk Formation'. Mapping of these two structures has been extended to the west of their transect to the SW face of Everest, and the Lhotse-Nuptse massif. For obvious reasons of extreme inaccessibility and danger, most of the rocks on Everest itself above $6000 \mathrm{~m}$ have not yet been directly 

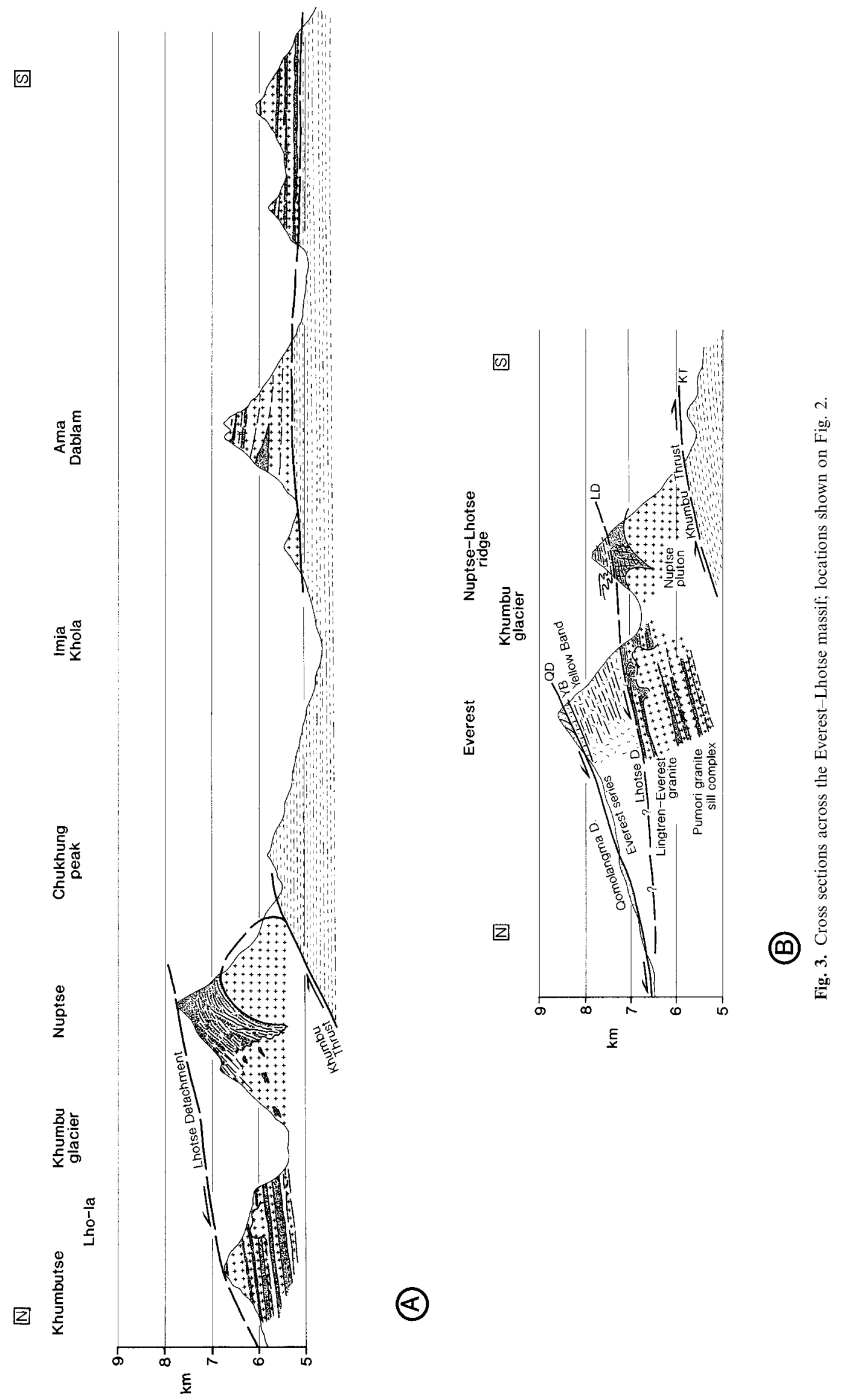

(ㄷ) 


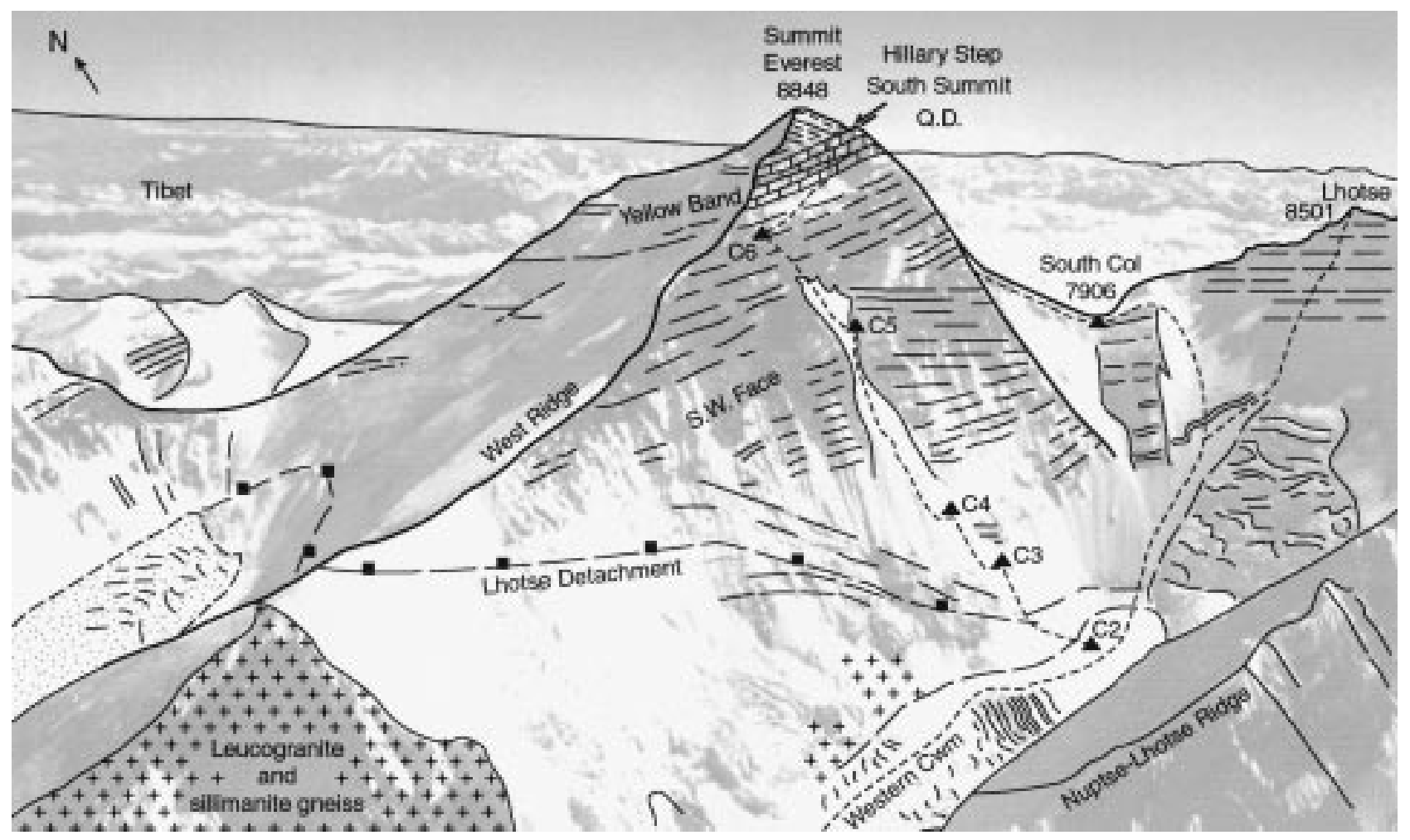

Fig. 4. Structure of the SW Face of Everest showing the Qomolangma Detachment (QD) and the Lhotse Detachment (LD), traced over an oblique aerial photograph in Bonington (1976). Dashed lines mark the climbing routes on Everest (SW Face and South Col routes) and Lhotse with regular camp sites marked on the SW Face route.

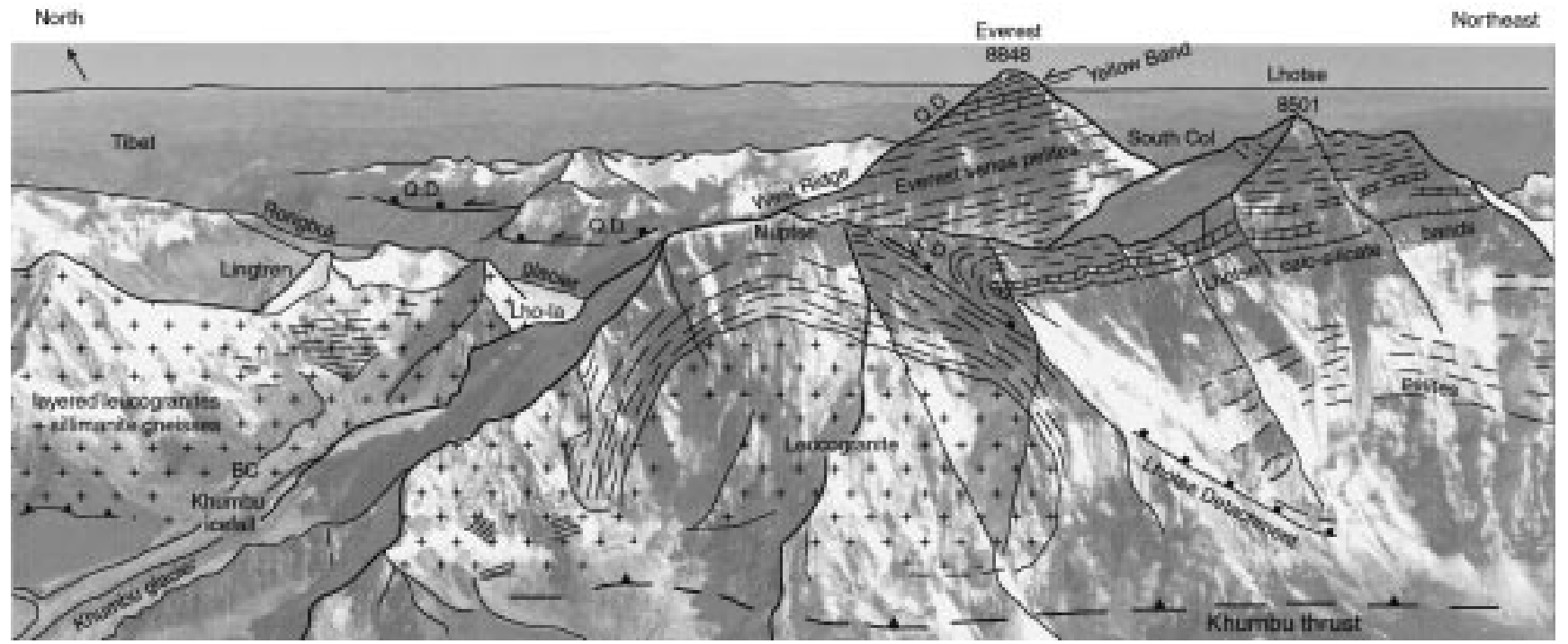

Fig. 5. Structure of the upper Khumbu Himalaya viewed from the south showing the South faces of Nuptse-Lhotse, traced over an aerial photograph by K. Ohmori. Note that the Lhotse Detachment is folded above the Nuptse leucogranite and the continuation of the leucogranite sheet into the Pumori-Lingtren peaks.

studied, although samples from the summit (1), Yellow Band (3), and Everest series pelites (4) collected by climbers on Everest in 1995 and 1997 have been studied here.

Using the National Geographic 1:50 000 scale topographic map as well as photos taken by climbers on Everest and aerial photos, a geological map of the Everest area has been compiled. Structural observations from the Western Cwm and Everest base camp area extend west to Cho Oyu and the
Ngozumpa glacier and around the Nuptse-Lhotse massif. On the basis of structural mapping around the Everest massif, aerial photo interpretation, metamorphic petrology and thermobarometry, two major extensional faults have been distinguished cutting the SW face of Everest-the upper Qomolangma Detachment and the lower, newly defined Lhotse Detachment (Fig. 4), and the structurally lower Khumbu thrust, which carries all the large-scale leucogranites 


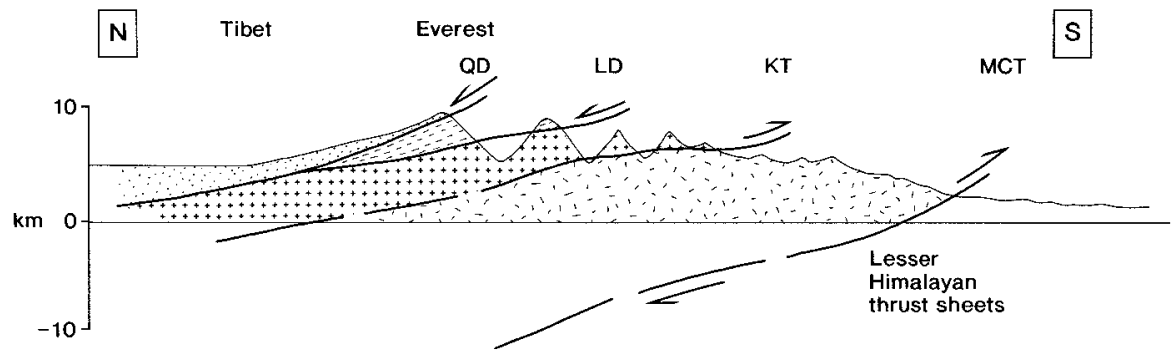

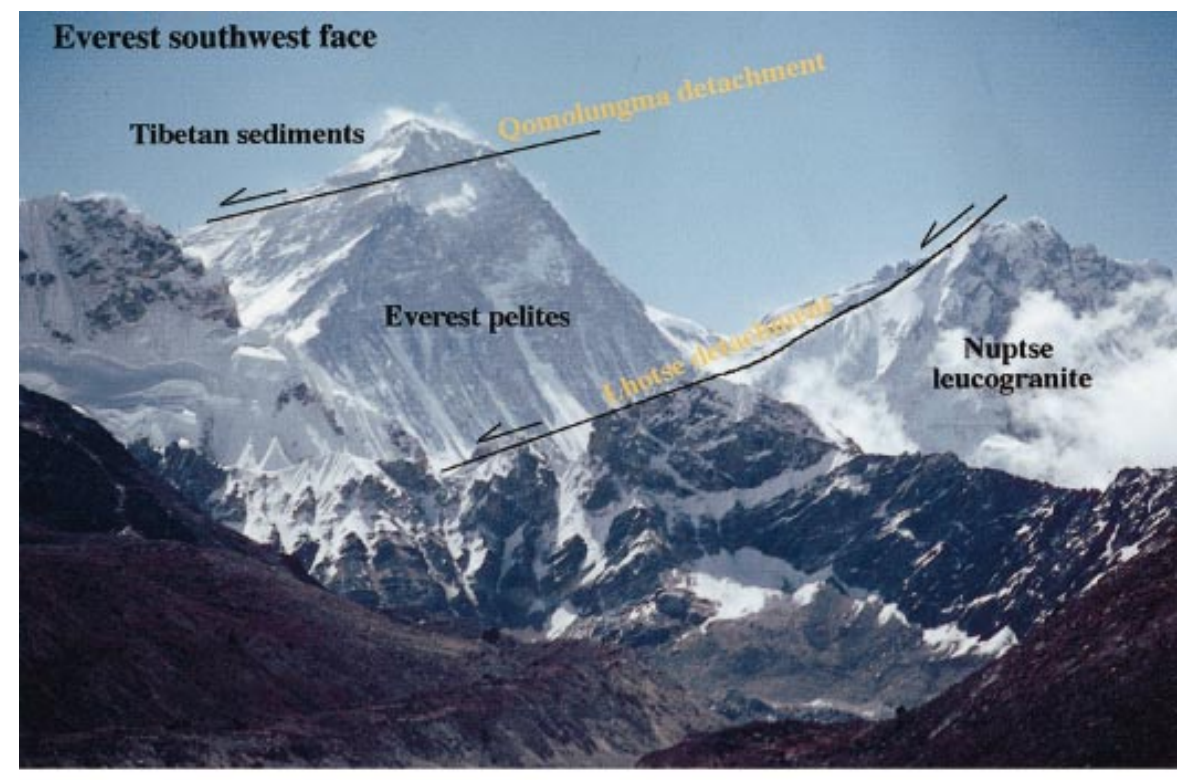

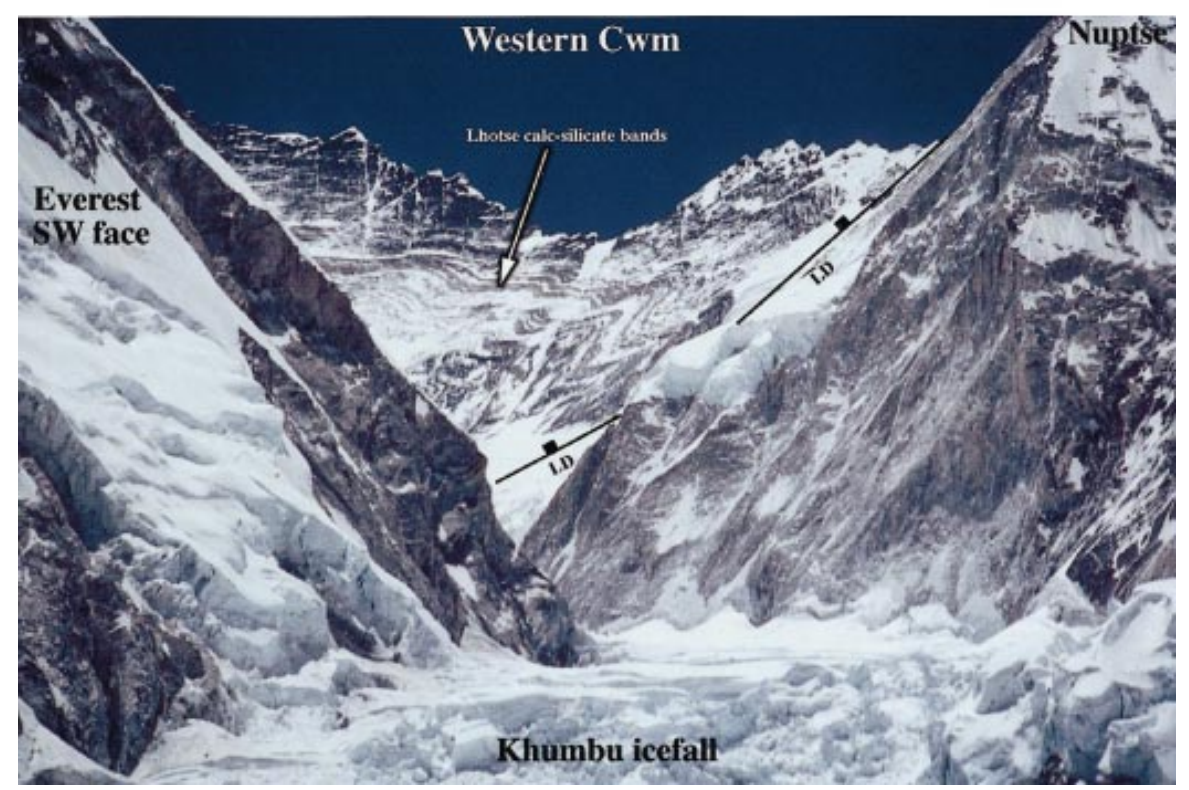

Fig. 6. Simplified sketch section across the Khumbu High Himalaya showing the geometry of the major faults.

Fig. 7. The southwest face of Everest $(8848 \mathrm{~m})$ viewed from the upper Ngozumpa glacier south of Cho Oyu, showing the two normal faults described here. The peak on the right is Nuptse.

Fig. 8. View east into the Western cwm between Everest (left) and Nuptse (right) showing S-vergent chevron folds in the Lhotse calc-silicate bands. LD is the Lhotse Detachment. 


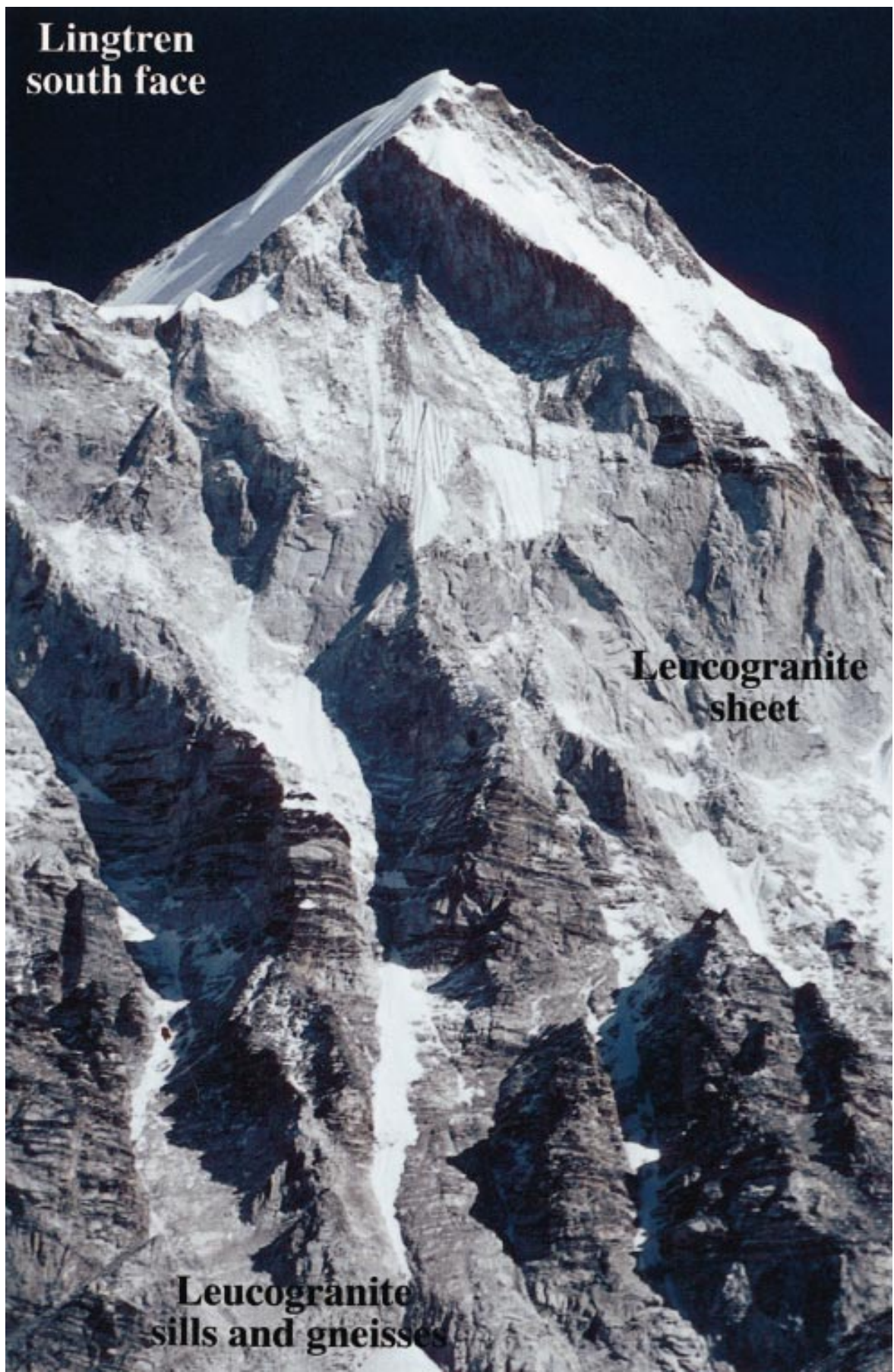

Fig. 9. Lingtren $(6749 \mathrm{~m})$ peak west of Everest Base Camp, showing a massive leucogranite sheet approximately $1000 \mathrm{~m}$ thick overlying the basal banded sillimanite grade gneisses with concordant leucogranite sills at the base.

in the Khumbu Himalaya southwards over the high grade gneisses (Rongbuk Fm., Black gneisses and Barun gneisses of Lombardo et al. (1993) and Namche migmatites) of the High Himalayan slab (Fig. 5). The simplified geometry of all the major faults in the Everest transect, including the Main Central Thrust, is shown in Fig. 6.

\section{Qomolangma Detachment}

The uppermost extensional fault, the Qomolangma Detachment has been mapped along the Rongbuk valley due north of Everest and has been traced up the northern flank of Everest to just below the summit, dipping at $5-15^{\circ} \mathrm{NE}$ (Burchfiel et al.
1992, fig. 19; Hodges et al. 1998). The latter authors dated the Rongbuk granite by $\mathrm{U}-\mathrm{Pb}$ and ${ }^{40} \mathrm{Ar} /{ }^{39} \mathrm{Ar}$ and precisely constrained movement along this segment of the South Tibetan Detachment as $16.67-16.37 \mathrm{Ma}$. The maximum age is from a mylonitized granite sill in the footwall of the Qomolangma Detachment, and the minimum age is from the undeformed Rongbuk granite which cross-cuts the Detachment. The Rongbuk granite is one of the few (?only) Himalayan granites that intrudes across the South Tibetan Detachment into the Tibetan sedimentary sequence hanging wall (Hodges et al. 1998). One apparent disparity between the observations on the north side of Everest and those from the Nepal (south) side reported here, is the metamorphic grade of rocks in the 
footwall of the Qomolangma Detachment. In the Rongbuk valley the footwall rocks are psammitic and pelitic schists containing the assemblage: quartz + biotite + garnet $+\mathrm{K}$ feldspar + plagioclase + sillimanite \pm cordierite (Hodges et al. 1992; Pognante \& Benna 1993), whereas on the SW face of Everest the metamorphic grade is much lower. Tourmaline and garnet-bearing leucogranitic sills and dykes can make up about $50 \%$ of the rock below the fault along the lower Rongbuk valley (Wager 1965). Nowhere along the trace of the Qomolangma Detachment can footwall rocks be matched with hanging-wall rocks and an absolute minimum of $34 \mathrm{~km}$ of displacement has been proposed (Burchfiel et al. 1992).

The summit of Everest (Fig. 7) is composed of unmetamorphosed, fine-grained silty limestone, which, in Tibet has been assigned an Ordovician age (Wang \& Zhen 1975; Yin \& Kuo 1978). Samples collected from the calc-silicate bands at c. $7700 \mathrm{~m}$ on the Lhotse face are strongly deformed marbles containing calcite + quartz + muscovite \pm biotite. These bands show conspicuous south vergent chevron folds in the headwall of the Western cwm on the Lhotse face (Fig. 8). Surrounding psammites, pelites and volcaniclastic metasediments from the Everest Series between the South Col and the South Summit of Everest are biotite grade and contain the assemblage albite + quartz+ biotite + chlorite+epidote. None of these samples contain aluminium silicates or garnet. Scapolite porphyroblasts are common and actinolite occurs in rocks with more volcaniclastic protoliths. Calcite + quartz + muscovite assemblages show strong deformation in the calcite twinning. The overall grade of the rocks from the Everest series schists on the South Face of Everest is probably no more than upper greenschist facies, although the presence of scapolite may indicate a medium-grade metamorphism. Precise $P-T$ conditions cannot be obtained from the mineral assemblages present. The major difference between the SW face of Everest and the Rongbuk glacier is that on Everest there are no leucogranites present in the Everest series pelites (Fig. 4), whereas along the Rongbuk glacier there are abundant leucogranite sills and dykes in the footwall rocks below the Qomolangma Detachment. Thus, it seems likely that the two detachments on Everest (Fig. 7) must merge to the north and there is no representation of the Everest series greenschist facies rocks along the Rongbuk valley.

\section{Lhotse Detachment}

A major normal fault, here termed the Lhotse Detachment, has been mapped along the flanks of the Western Cwm of Everest (Fig. 4) and on the Lhotse Face (Fig. 5). This fault separates biotite grade middle-upper greenschist facies rocks of the Everest series above from sillimanite-K-feldspar-grade rocks with abundant leucogranites, dykes and sills below. The differences in metamorphic grade across the Lhotse Detachment suggest that there is a much greater, although unquantified, amount of throw and displacement along this fault than the structurally higher Qomolangma Detachment. The Lhotse Detachment runs above the Lho-la $(6026 \mathrm{~m})$ and continues westwards above (north of) the mountains of Khumbutse $(6665 \mathrm{~m})$, Lingtren $(6749 \mathrm{~m})$ and Pumori $(7148 \mathrm{~m})$ in Tibet (Fig. 2). The fault dips down to the upper part of the Khumbu glacier above the icefall and cuts across the Lhotse face (Figs 4 \& 5). All leucogranites, both dykes and sills as well as the large-scale plutons such as the Nuptse granite, are all within the footwall of the Lhotse Detachment. The Everest series pelites above the Lhotse Detachment appear to contain no leucogranites.

Metamorphism beneath the Lhotse Detachment shows a variety of sillimanite-grade biotite paragneisses, garnet + diopside+ plagioclase calc-silicates, hornblende+diposide + biotite amphibolites. The lack of kyanite at high structural levels within the slab, together with the presence of andalusite, cordierite and sillimanite all suggest high- $T$ low- $P$ metamorphism. Pognante \& Benna (1993) reported $P-T$ data from two samples of sillimanite + biotite + garnet + cordierite + andalusite gneiss from the upper part of the slab. The range of $P-T$ conditions from one sample $\left(570-670^{\circ} \mathrm{C}\right.$ and $2.4-5.0 \mathrm{kbar}$ (garnet core) and $490-580^{\circ} \mathrm{C}$ and 3.0-5.5 kbar (garnet rim) and another sample (range $730-950^{\circ} \mathrm{C}$ and $4.3-7.5 \mathrm{kbar}$ (garnet core) and $470-580^{\circ} \mathrm{C}$ and $3.0-5.6 \mathrm{kbar}$ (garnet rim)) are very large and dependent on the individual thermometers and barometers used. This data cannot be used to accurately constrain the depth of formation because the range and uncertainies are so great. However, the presence of andalusite suggests that pressures cannot have exceeded $3.8 \mathrm{kbars}$, and the cordierite forming reaction:

$$
\text { garnet }+\mathrm{Al}_{2} \mathrm{SiO}_{5}+\text { quartz }+\mathrm{H}_{2} \mathrm{O}=\text { cordierite }
$$

also suggests that pressures were $<4$ kbar.

The Lhotse Detachment has been folded around the major granite bodies. On Lhotse the fault dips east (Fig. 8) curving above the large Nuptse granite pluton to the west and plunging down to the Imja Khola in the east. Prominent calc-silicate bands below the Lhotse ridge are flat-lying until approaching the fault and then suddenly folded into a tight SW-vergent fold (Fig. 5). The black schists on Lhotse are assumed to be greenschists because they are traceable directly into the biotite grade psammites and pelites on the SW face of Everest (Figs 3 $\&$ 5). Because the Lhotse Detachment has been folded, it is assumed to be older in age than the structurally higher Qomolangma Detachment. Whereas the footwall of the QD on Everest is mid-upper greenschist facies, along the Rongbuk glacier to the north, footwall rocks are sillimanite grade, upper amphibolite facies (Hodges et al. 1992; Pognante \& Benna 1993). It is proposed here that the two normal faults converge at depth towards the north beneath Everest, with the Everest series greenschists forming a northward tapering wedge (Fig. 6).

\section{Khumbu Thrust Sheet and Everest-Nuptse leucogranites}

The leucogranites exposed around Everest Base camp form part of a large interconnected granite sheet beneath the Lhotse Detachment, all at roughly the same structural level (Figs 5 \& 6). The Everest-Nuptse leucogranites are connected eastwards to the Makalu granite and westwards to the Lingtren and Pumori granite sheets, which continue along the Nepal-Tibet border to at least the Gyachung Kang and Cho Oyu regions. Earlier descriptions of the major Himalayan leucogranites being isolated plutons (e.g. Le Fort et al. 1987) are not correct, neither in Nepal nor in the Zanskar and Garhwal Himalaya in India (Searle et al. 1988, 1993). The Shisha Pangma leucogranite forms part of a sheet of leucogranite which extends eastwest for c. $45 \mathrm{~km}$ (Searle et al. 1997a). Likewise, the Everest leucogranites are all part of one structural horizon which can be directly traced from at least the Makalu massif in the east to Cho Oyu in the west, a distance of $>35 \mathrm{~km}$. The geometry of these leucogranites in north Nepal rules out diapirism as an 
emplacement mechanism. Rather each major leucogranite body has been fed by a series of layer-parallel sills which intrude along the schistosity planes during active simple shear (Weinberg \& Searle in press). Passive injection of magma, probably by hydraulic fracturing, is apparent from the concordant xenolithic remnants of the high grade gneisses within some of the larger sills.

Above Everest Base Camp and on the south face of Lingtren and Pumori spectacular granite sheets dip at shallow angles $\leq 15^{\circ} \mathrm{N}$ (Fig. 9). These leucogranite sheets are parallel to the foliation in the sillimanite gneisses and have some interconnecting dykes. The thickest granitic sheet, containing a few xenolithic rafters of sillimanite gneiss, is around $2000 \mathrm{~m}$ and comprises most of the upper walls of Lingtren (Fig. 9). The main emplacement mechanism for these leucogranites is clearly one of magma transport along sills from the source region at depth to the north. South of the Everest-Nuptse massif, several isolated high peaks are composed mainly of flat-lying leucogranite sheets. These include the mountains Ama Dablam (Fig. 10), Tamserku and Kangteiga (Fig. 3a). Beneath these isolated klippen of leucogranites, massive black sillimanitegrade schists with little or no granitic melts or dykes are present. Although migmatites do occur at structurally lower levels (Namche migmatites) no migmatites are present in the black schists, which cannot be the direct source for the granite melts.

Along the south face of Nuptse, the Nuptse granite shows a spectacular south-vergent fold (Fig. 11). Foliation in the sillimanite gneisses wraps around the granite and is inverted along the base of the fold above the Khumbu thrust. Compressional shear fabrics, including narrow ductile shear zones with mylonites, are widespread along this horizon which extends west and cuts across the lower Khumbu glacier and further to the west of Lobuche (Fig. 2). The Khumbu thrust can be traced along the lower third of the Lhotse south face where it is inaccessible. Along the footwall of the Khumbu thrust, the foliation flattens out along the Chukhung ridge southwards to Ama Dablam and the Kangteiga-Tamserku klippen. The divergence of foliation together with the compressional shear fabrics strongly suggests that a major flat-lying thrust, the Khumbu thrust, underlies the klippen extending at least $25 \mathrm{~km}$ south of the Everest area. The upper part of the SW face of Nuptse shows a spectacular dyke network emanating from the roof of the Nuptse leucogranite pluton (Fig. 12). These dykes are both parallel to, and cut across, the foliation. Two larger dykes emanating from the eastern end of the Nuptse granite appear to be truncated by the overlying Lhotse detachment, although this part of the south face is inaccessible. The major leucogranites are restricted to this structural level, bounded by the Lhotse detachment above and the Khumbu thrust below. Overall structural relationships are similar to those described from the Annapurna region (Hodges et al. 1996) and Shisha Pangma regions to the west (Searle et al. 1997a) and the Bhutan (Swapp \& Hollister 1991) and Khula Kangri regions to the east (Edwards et al. 1996), where south-vergent thrust systems break back in the sequence within the middle of the High Himalayan slab.

\section{Regional geometry and magnitude of displacement along normal faults}

The regional geometry of the High Himalayan slab in the Khumbu Himalaya is shown in Fig. 6. In the Everest area, the
Lhotse Detachment is clearly the major normal fault with a large jump in $P-T$ conditions across the fault. Unfortunately, the precise $P-T$ conditions of the Everest series pelites overlying the Lhotse Detachment are difficult to obtain mainly due to the lack of garnet in these biotite-grade rocks. Burchfiel et al. (1992) constrained the minimum offset along the Qomolangma Detachment as $35 \mathrm{~km}$, the distance between the northern extent of footwall metamorphic rocks in the Rongbuk valley and the southern limit of hanging-wall sediments on the summit of Everest. The same exercise for the Lhotse Detachment reveals a minimum displacement of $40 \mathrm{~km}$ from the northern limit of footwall rocks in Rongbuk to the southern limit of the Everest series greenschists on the south face of Lhotse.

Pressures of the sillimanite grade rocks (Pognante \& Benna 1993) in the footwall of the Lhotse Detachment could correspond to depths of formation as shallow as $8.5 \mathrm{~km}$ or as deep as $26 \mathrm{~km}$ assuming a pressure gradient of $3.5 \mathrm{~km} \mathrm{kbar}^{-1}$. Assuming a conservative 4-5 kbar pressure of sillimanite-grade metamorphism, depths of burial during peak metamorphism would have been 14-17.5 km (Fig. 13). Folding and thrusting of Indian plate margin Tethyan sediments, north of the South Tibetan Detachment and south of the Indus suture zone would have thickened the upper crust above the Detachment, but it is impossible to constrain the amount. Assuming an average dip on the South Tibetan Detachment of $20^{\circ} \mathrm{N}$ and a minimum displacement of $40 \mathrm{~km}$ along the Lhotse Detachment, the exhumation pathway of a rock formed at $4 \mathrm{kbar}$ and $5 \mathrm{kbar}$ respectively is shown in Fig. 13. The Yellow Band represents metamorphosed Ordovician limestone at the base of the Tethyan sedimentary sequence, above which some $6 \mathrm{~km}$ of the stratigraphy has been removed by erosion. The Everest series greenschists shown in the wedge, bounded by the Qomolangma Detachment above and the Lhotse Detachment below, would have a displacement of around $10-12 \mathrm{~km}$ southwards. The restoration in Fig. 13 shows that the protoliths for the Everest series schists are likely to be the Cambrian black shales beneath the Ordovician limestones.

\section{Relations between normal faulting and thrust faulting in Khumbu Himalaya}

Although the overall structure of the High Himalayan slab is well-known, that of a northward tapering wedge bounded by the Main Central Thrust along the base and the South Tibetan Detachment normal fault system along the top, several complexities are now emerging. These include the presence of out-of-sequence thrusts which have the effect of accommodating continual crustal thickening by maintaining the load, and thereby keeping the pressures and temperatures high enough for peak metamorphic conditions. Multiple phases of thrusting and normal faulting within the High Himalayan slab have now been well documented, both in the Tethyan sedimentary rocks of the north Indian plate margin (Searle et al. 1997b) and in the High Himalayan zone in the Annapurna region (Hodges et al. 1996). England \& Molnar (1993) suggested that the cause of Miocene normal faulting was either uplift of the Himalaya or cessation of slip along the Main Central Thrust and transference of slip to a lower thrust, such as the Main Boundary Thrust. However, it is clear that normal faulting did not follow after thrusting, but was broadly synchronous and that normal faulting along the South Tibetan Department 

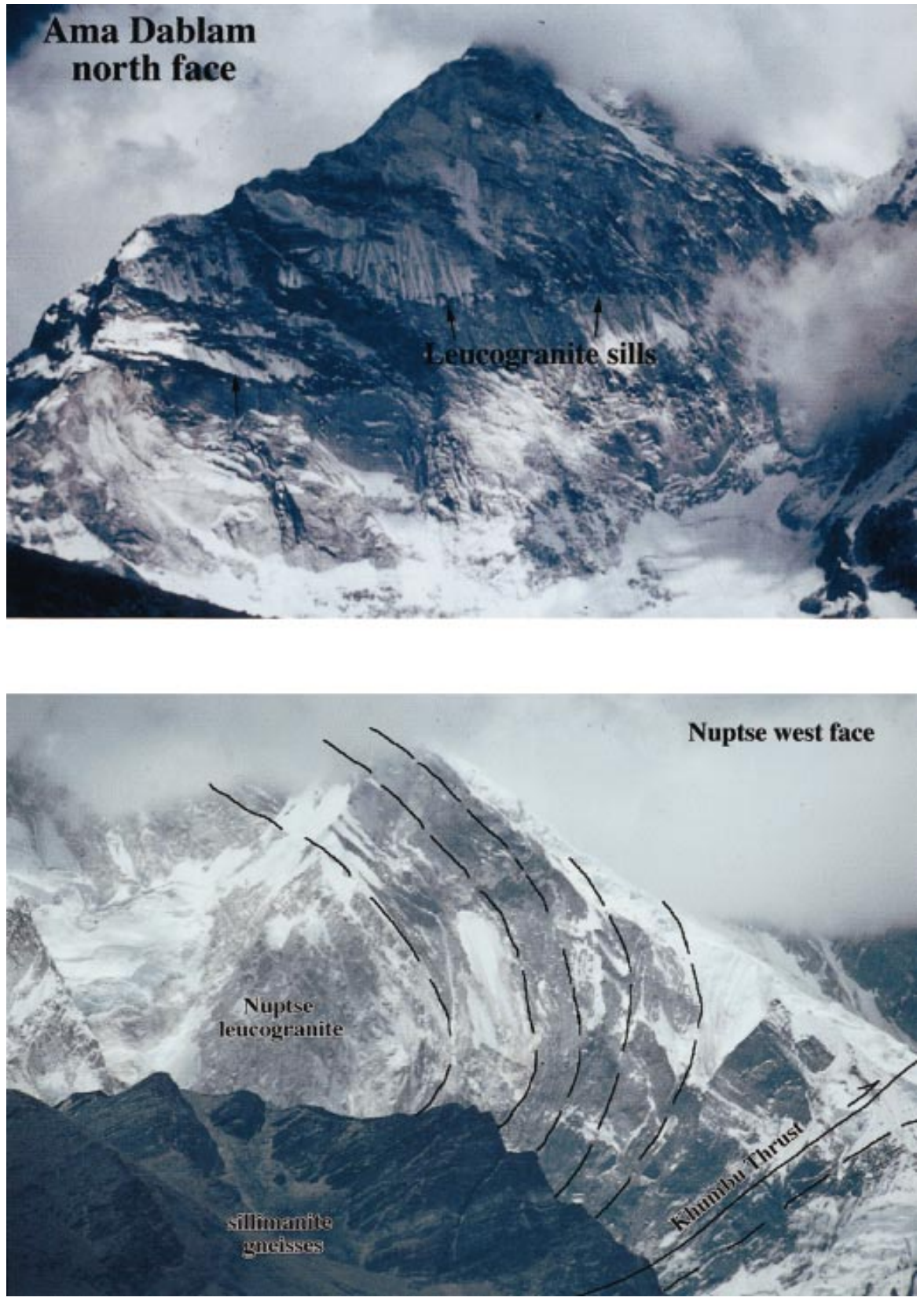

Fig. 10. North face of Ama Dablam (6856 m) showing horizontal leucogranite sheets with aligned and parallel rafters or xenoliths of metamorphic country rock in between. Ama Dablam forms a large klippe of leucogranite emplaced above black sillimanite grade gneisses.
Fig. 11. View of the part of the south face of Nuptse $(7845 \mathrm{~m})$ showing the south vergent fold of the leucogranite above the Khumbu Thrust. Foliation in the surrounding sillimanite grade gneisses wraps around the granite and is discordant either side of the thrust along the base. coupled with thrusting along the Main Central Thrust was responsible for uplift, erosion and exhumation of the High Himalaya.

On the Nepalese side of Everest, final motion along the Lhotse Detachment occurred after crystallization of the leucogranites, because the leucogranites are cut by the fault. Along the Rongbuk valley in Tibet earlier leucogranites have been sheared in the footwall of the Qomolangma Detachment whilst the Rongbuk pluton intrudes across the fault (Hodges et al. 1998). While the Rongbuk granite has proven extremely difficult to date by $\mathrm{U}-\mathrm{Th}-\mathrm{Pb}$ geochronology, due to massive contamination by xenocrystic phases, published age estimates so far have been 21-20 Ma (Copeland 1990; Copeland et al. 1988), 21.6-19.5 Ma (Hodges et al. 1992) and 23.0-21.5 Ma (Harrison et al. 1995). Recently, Hodges et al. (1998) have constrained the age of normal faulting on this strand of the
Qomolangma Detachment to be between 16.37 and $16.67 \mathrm{Ma}$ from $\mathrm{U}-\mathrm{Pb}$ and ${ }^{40} \mathrm{Ar} /{ }^{39} \mathrm{Ar}$ geochronology. $\mathrm{U}-\mathrm{Pb}$ monazite ages from leucogranites in the Everest area also include the Makalu granite dated at $21.9 \pm 0.2 \mathrm{Ma}$ and $24.0 \pm 0.4 \mathrm{Ma}$ (Schärer 1984) and a granite north of Everest dated at $14.3 \pm 0.6 \mathrm{Ma}$ (Schärer et al. 1986). Final motions along strands of the South Tibetan Detachment normal faults have now been dated as younger than 19.5 Ma in Zanskar (Noble \& Searle 1995), $<17.3 \pm 0.2 \mathrm{Ma}$ at Shisha Pangma (Searle et al. 1997a), <16.37-16.67 Ma at Rongbuk (Hodges et al. 1998) and $<12.5 \pm 0.4 \mathrm{Ma}$ at Khula Kangri (Edwards \& Harrison 1997). Motion along the Main Central Thrust and the South Tibetan Detachment could have been episodic and both fault zones appear to show late-stage reactivation, but both must also have been mechanically linked throughout the exhumation history of the High Himalayan slab. 


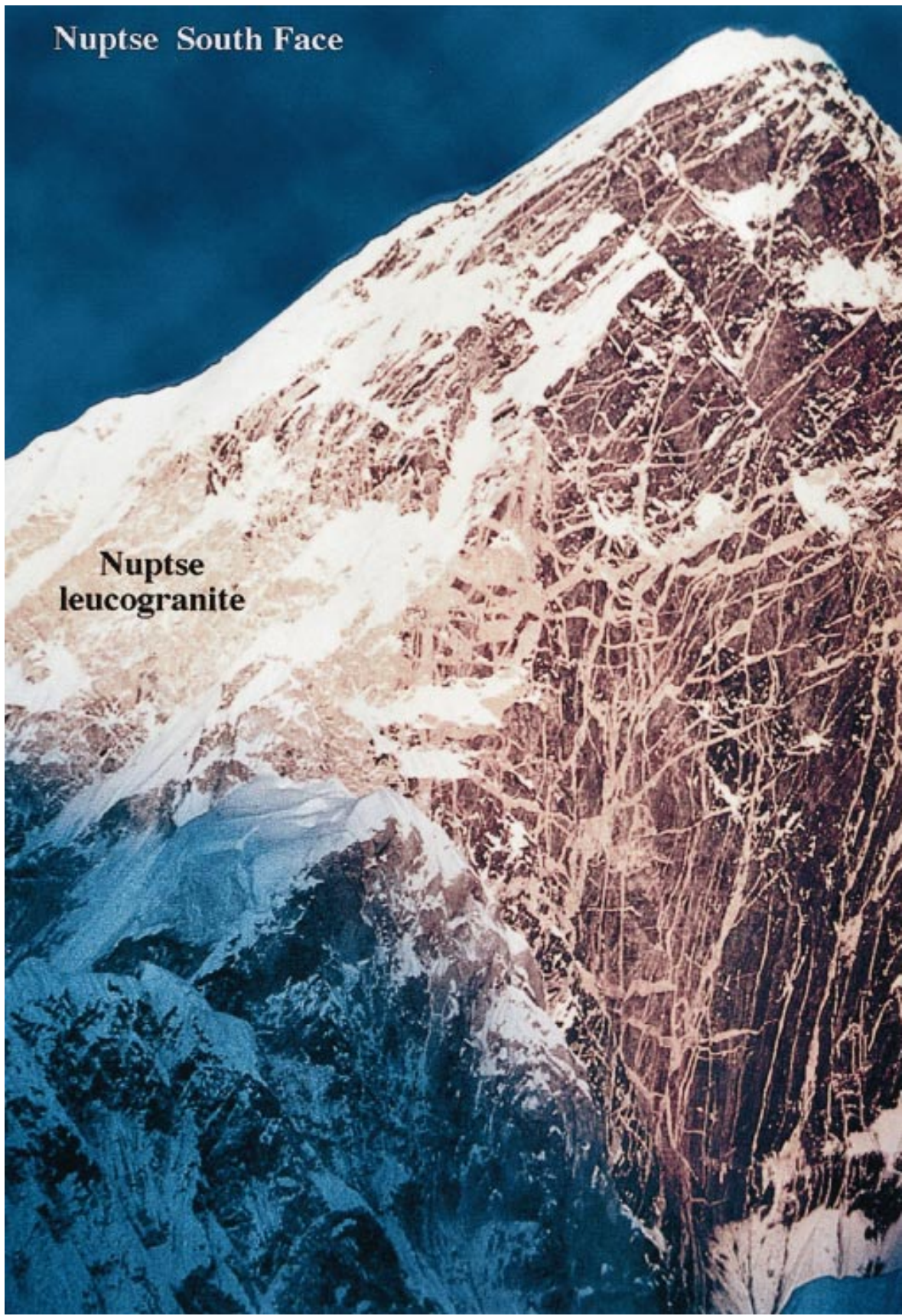

Fig. 12. Dyke network emmanating from the upper part of the Nuptse leucogranite exposed on the 'Spider Wall', the SW face of Nuptse (7845 m).

\section{Decompression melting by normal faulting: cause or effect of rapid exhumation?}

Petrological and thermobarometric evidence suggest that somewhere between 12 and $25 \mathrm{~km}$ of overburden was removed by uplift of the rocks along the hanging wall of the basal (Main Central) thrust fault and extensional unroofing in the footwall of the South Tibetan Detachment normal faults, while these rocks were at amphibolite facies conditions (Hodges et al. 1992). In most cases the South Tibetan Detachment normal faults clearly cut and truncate fabrics and structures in the footwall suggesting later brittle motion. Decompression melting along the footwall of the South Tibetan Detachment has been cited as the main process responsible for the formation of the leucogranites (Harris \& Massey 1994). The structural location of the leucogranites immediately beneath the South Tibetan Detachment normal faults suggests a strong link with extensional motion, even though the source region must have been deeper and further north than the present location (Fig. 13). The fact that the normal fault, in almost every case, cuts the leucogranites in the footwall, however, suggests that final motion along the South Tibetan Detachment at least was later than the final emplacement of the granite. If normal faulting was the cause of melting then it must have been along earlier faults than the South Tibetan Detachment system as mapped today. Clearly there is strong evidence for multiple timing of normal fault motion. As long as the main driving force (India's northward relative motion) remained constant, then crustal material along the Himalaya was constantly being underthrust towards the north, buried, metamorphosed, occasionally melted, and then 

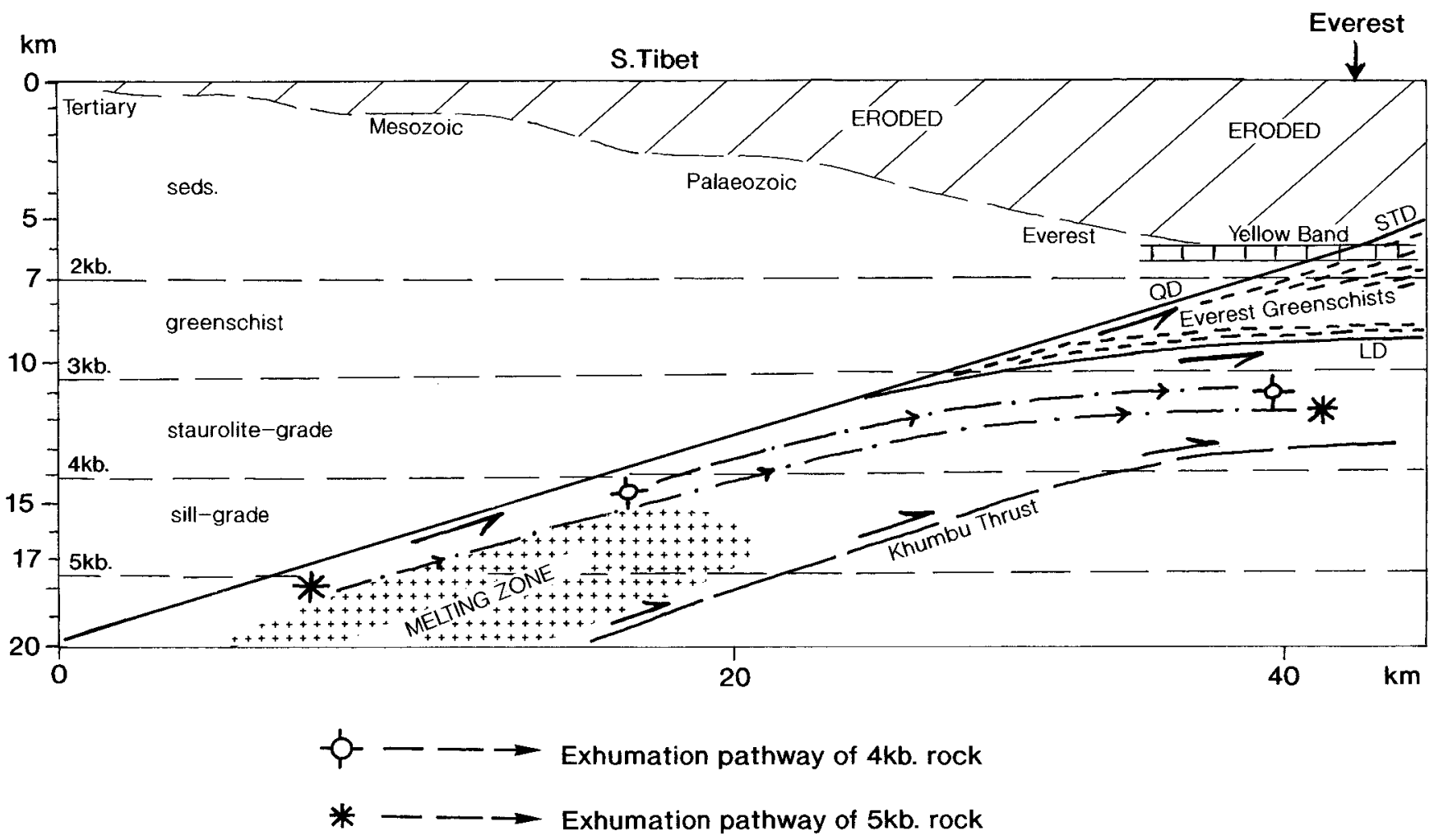

Fig. 13. Restored section from Everest northwards showing the approximate position of the Himalayan metamorphic isograds, the position of the Lhotse and Qomolangma Detachments and the exhumation pathways of rocks formed at 4 and $5 \mathrm{kbar}$ in the footwall of the Lhotse Detachment. High ductile strain in the rocks below the Lhotse Detachment during shearing and exhumation resulted in thinning of the section. The shaded area at the top shows the rock section which has been removed by erosion.

rapidly exhumed along the footwall of the South Tibetan Detachment system. A review of all radiometric ages along the High Himalaya (Searle 1996) shows that most melting occurred between $c .21$ and $17 \mathrm{Ma}$, and the period of rapid exhumation, as documented by rapid cooling (from at least melting temperatures of $750-700^{\circ} \mathrm{C}$ to $c .250^{\circ} \mathrm{C}$ ) was between $c .17$ and $14 \mathrm{Ma}$ in the central Nepal-south Tibet Himalaya.

It seems necessary that, with crustal scale structures such as the South Tibetan Detachment, a long-lasting history started with deep, ductile movement at depth in the crust in amphibolite facies conditions and ended with high-level brittle normal faulting. It should be no surprise that radiometric ages differ (by c. $11 \mathrm{Ma}$ ) along the strike of this structure as it was one of the major faults which was responsible for the exhumation and topographic uplift of the High Himalayan range from the early Miocene to the present day.

\section{Everest to Tibet: Mid-crustal melting zone beneath the Tibetan Plateau}

The rocks exposed between the Lhotse Detachment and the Khumbu thrust show HT-LP metamorphism, anatexis and leucogranites which were formed between 24 and $12 \mathrm{Ma}$ ago. The North Himalayan gneiss domes, which form a series of domal structures within the Tethyan sediments north of the High Himalaya (Fig. 1), are cored by leucogranitic melts formed approximately 15-9 Ma ago. Both granitic belts were probably produced from the same processes of partial melting within the High Himalayan thrust wedge (Fig. 13). Heat flow data from southern Tibet imply that granite minimum melt temperatures should be reached at $c .15 \mathrm{~km}$ depth beneath Yamdrock tso, in SE Tibet (Francheteau et al. 1984). Such shallow depths of present-day melting conditions combined with the low pressures and high structural levels of melting within the High Himalayan slab strongly suggest that melting cannot be linked to shear heating along the Main Central Thrust or along the Main Himalayan Thrust basal detachment of the Himalaya, as suggested by England et al. (1992) and Harrison et al. (1997b). Nowhere along the Himalayan chain are leucogranites presently found along the trace of the Main Central Thrust, which is usually marked by a zone of inverted metamorphic isograds from kyanite to chlorite-biotite grade.

The INDEPTH geophysical profile across south Tibet, north of Bhutan, revealed a prominent mid-crustal low-velocity zone from the shear wave velocity profile north of the IndusTsangpo suture (Nelson et al. 1996). These authors interpreted this mid-crustal 'mush' as a zone of partially molten crust extending from $c .15 \mathrm{~km}$ depth to $c .50 \mathrm{~km}$ depth for over $225 \mathrm{~km}$ north of the High Himalaya, with 'bright spots' reflecting the presence of fluid, probably granitic magma (Brown et al. 1996; Nelson et al. 1996). Although these 'bright spots' may represent trapped interconnected aqueous fluids rather than true magma, it seems highly likely than the fluids are of migmatitic or partial melt origin, given the known geology of the High and North Himalayan granite belts. 


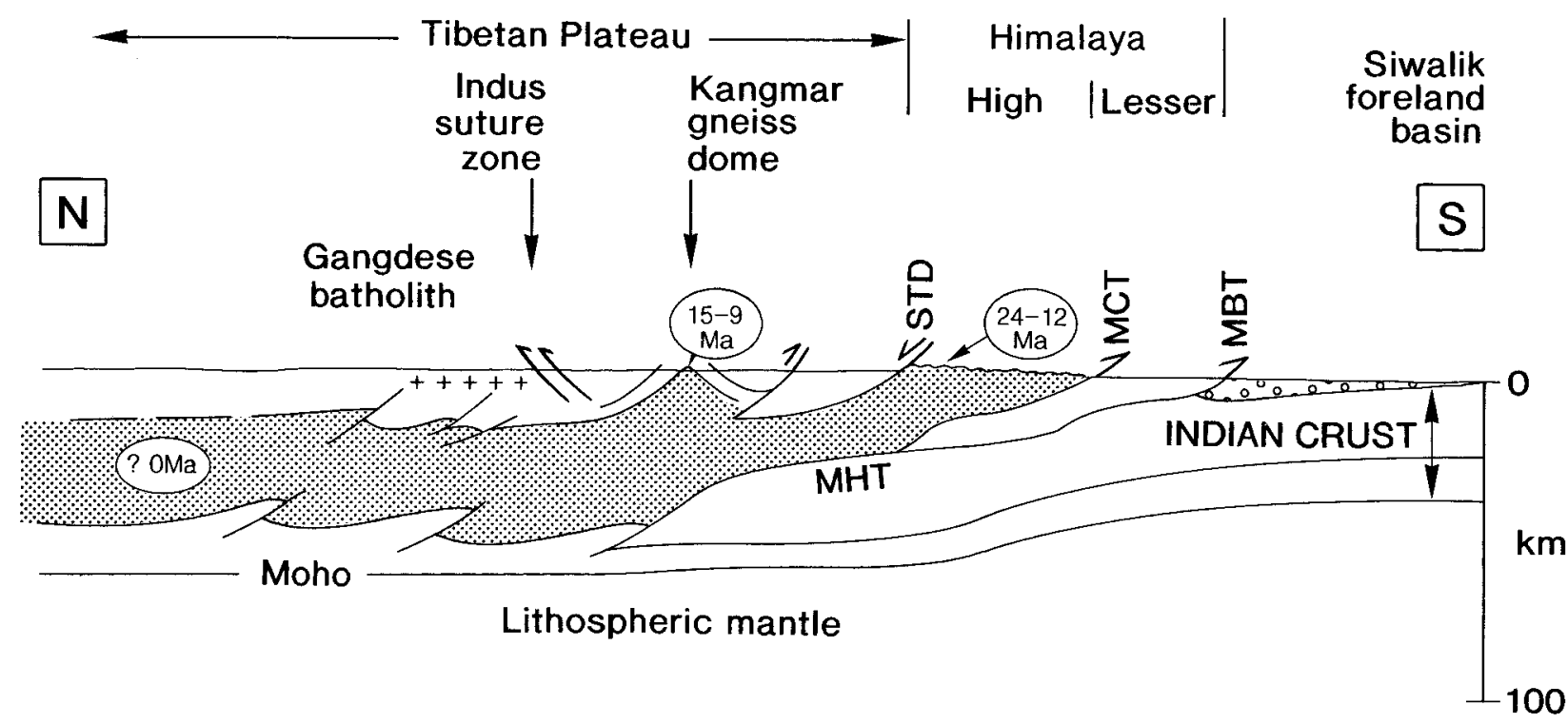

Zone of regional metamorphism and partial melting

24-12) Range of known $\mathrm{U}-\mathrm{Pb}$ zircon, monazite ages of crustal melting

Fig. 14. Cross-section of the Himalaya and south Tibet, simplified after the INDEPTH seismic reflection profile (Nelson et al. 1996) showing the link between the mid-crustal zone of partial melting and melt formation with the older regional metamorphic, migmatitic and leucogranitic rocks of the High Himalaya. The range in $\mathrm{U}-\mathrm{Pb}$ ages of leucogranites in each zone are also given.

Whatever the composition of these fluids, the high electrical conductivity and passive seismic observations (S-wave lowvelocity zone) implies the existence of a layer in the middle crust of south Tibet which contains interconnected fluids.

It is suggested that these rocks are migmatites forming today within a layer bounded by the South Tibetan extensional detachment above and the northward extension of the Main Central Thrust below. It is further suggested that similar processes of crustal thickening, metamorphism, melting and leucogranite genesis are occurring today in this zone beneath the Tibetan Plateau as were occurring during the early and mid-Miocene along the High Himalaya (Fig. 14). The major reflectors or décollements imaged on seismic profiles beneath Tibet are continuous southward with older detachments which can be seen and mapped in the Everest-Lhotse Himalaya. Recent results from $\mathrm{U}-\mathrm{Pb}$ monazite dating of leucogranites across the southward continuation of this zone in South Tibet, north of Bhutan, suggest a northward younging of crystallization ages from c. 23 and $12 \mathrm{Ma}$, consistent with the southward extrusion of the High Himalaya (Wu et al. 1998). The weak lower crust represented by the High Himalayan rocks, deformed by plastic, ductile flow, has been decoupled from the more brittle, deformed upper crust along these large-scale detachments of the South Tibetan Detachment system. The fate of high-grade metamorphic rocks and leucogranites formed today beneath Tibet is predicted to flow southward, eventually to be uplifted, exhumed and eroded along a migrating High Himalayan axis.

This work was supported by NERC (UK) grant GT5/96/13/E to M.P.S. Thanks to I. Brewer and R. Weinberg for assistance in the field and to J. Tinker, N. Kekus, H. Magnusson and S. Yates for collecting rocks high on Everest and Lhotse. Thanks to K. Hodges,
B. Lombardo and P. Pertusati for discussions about the structure, petrology and dating of Everest rocks and for sending preprints of their work, and thanks to M. Hubbard, D. Nelson, K. Hodges and S. Inger for helpful reviews. Thanks also to S. Baker for help with digital imaging and R. McAvoy and D. Sansom for help with the graphics.

\section{References}

Bonington, C. 1976. Everest The Hard Way, The First Ascent of the Southwest Face. Hodder and Stoughton.

Brown, L.D. \& 9 others. 1996. Bright Spots, structure and magmatism in Southern Tibet from INDEPTH seismic reflection profiling. Science, 274, 1688-1690.

Brunel, M. 1986. Ductile thrusting in the Himalaya: shear sense criteria and stretching lineations. Tectonophysics, 5, 247-265.

Burchfiel, B.C., Zhiliang, C., Hodges, K.V., Yuping, L., Royden, L., Changrong, D. \& Jiene, X. 1992. The South Tibetan Detachment System, Himalaytan Orogen: extension contemporaneous with and parallel to shortening in a collisional mountain belt. Geological Society of America Special Paper, 269.

Burg, J-P. 1983. Carte Geologique du Sud du Tibet. Ministry of Geology, Peking, and CNRS, Paris.

— Brunel, M., Gapais, D., Chen, G.M. \& Liu, G.H. 1984. Deformation of leucogranites of the crystalline Main Central thrust sheet in southern Tibet (China). Journal of Structural Geology, 6, 535-542.

Copeland, P. 1990. Cenozoic tectonic history of the Southern Tibetan Plateau and Eastern Himalaya: Evidence from ${ }^{40} \mathrm{Ar} /{ }^{39} \mathrm{Ar}$ dating. PhD thesis State University of New York, Albany, USA.

— PARrish, R.R. \& HARRISON, T.M. 1988. Identification of inherited radiogenic $\mathrm{Pb}$ in monazite and its implications for $\mathrm{U}-\mathrm{Pb}$ systematics. Nature, 333, 760-763.

Edwards, M.A., Kidd, W.S.F., Li, J., Yue, Y. \& Clark, M. 1996. Multi-stage development of the southern Tibet detachment system near Khula Kangri. New data from Gonto-la. Tectonophysics, 260, 1-19.

Edwards, M.A. \& Harrison, T.M. 1997. When did the roof collapse? Late Miocene north-south extension in the high Himalaya revealed by $\mathrm{Th}-\mathrm{Pb}$ monazite dating of the Khula Kangri granite. Geology, 25, 543-546. 
England, P. \& Molnar, P. 1993. Cause and effect among thrust and normal faulting, anatectic melting and exhumation in the Himalaya. In: TreloAR, P.J. \& Searle, M.P. (eds) Himalayan Tectonics. Geological Society, London, Special Publications, 74, 401-411.

—, Lefort, P., Molnar, P. \& Pecher, A. 1992. Heat sources for Tertiary metamorphism and anatexis in the Annapurna-Manaslu region, central Nepal. Journal of Geophysical Research, 97, 2107-2128.

Francheteau, J., Jaupart, C., Xian, J.S., Wen-Hua, K., De-Lul, Jia-Cha, B. Huang-Pin, W. \& Hsia-Yeu, D. 1984. High heat flow in southern Tibet. Nature, 307, 32-36.

Gansser, A. 1964. Geology of the Himalayas. John Wiley \& Sons, Chichester, UK.

Harris, N. \& Massey, J. 1994. Decompression and anatexis of Himalayan metapelites. Tectonics, 13, 1537-1546.

Harrison, T.M., Lovera, O. \& Grove, M. 1997b. New insights into the origin of two contrasting Himalayan granite belts. Geology, 25, 899-902.

—, McKeegan, K.D. \& Lefort, P. 1995. Detection of inherited monazite in the Manaslu leucogranite by ${ }^{208} \mathrm{~Pb} /{ }^{232} \mathrm{Th}$ ion microprobe dating: Crystallization age and tectonic implications. Earth and Planetary Science Letters, 133, 271-282.

—, Ryerson, F.J., Lefort, P., An Yin, Lovera, O.M. \& Catlos, E.J. 1997a A Late Miocene-Pliocene origin for the Central Himalayan inverted metamorphism. Earth and Planetary Science Letters, 146, E1-E7.

Hodges, K.V., Bowring, S., DavideK, K., Hawkins, D. \& Krol, M. 1998. Evidence for rapid displacement on Himalayan normal faults and the importance of tectonic denudation in the evolution of mountain ranges. Geology, 26, 483-486.

—, Burchriel, B.C., Royden, L.H., Chen, Z. \& Liu, Y. 1993. The metamorphic signature of contemporaneous extension and shortening in the central Himalayan orogen: data from the Nyalam transect, southern Tibet. Journal of Metamorphic Geology, 11, 721-737.

- Parrish, R.R., Housch, T.B., Lux, D.R., Burchfiel, B.C., Royden, L.H. \& CHEN, Z. 1992. Simultaneous Miocene extension and shortening in the Himalayan orogen. Science, 258, 1466-1470.

- \& SeARle, M.P. 1996. Tectonic evolution of the central Annapurna Range, Nepalese Himalaya. Tectonics, 15, 1264-1291.

HubBard, M.S. 1989. Thermobarometric constraints on the thermal history of the Main Central Thrust Zone and Tibetan Slab, eastern Nepal Himalaya. Journal of Metamorphic Geology, 7, 19-30.

— H HARRISON, T.M. 1989. ${ }^{40} \mathrm{Ar} /{ }^{39} \mathrm{Ar}$ age constraints on deformation and metamorphism in the Main Central Thrust zone and Tibetan Slab, eastern Nepal Himalaya. Tectonics, 8, 865-880.

Le Fort, P., Cuney, M., Deniel, C., France-Lanord, C., Sheppard, S.M.F., Upreti, B.N. \& VidAL, P. 1987. Crustal generation of Himalayan leucogranites. Tectonophysics, 134, 39-57.

Lombard, A. 1958. Un itineraire geologique dans l'est du Nepal (Massif du Mont Everest). Memoires de la Societe Helvetique des Sciences Naturelles, 82.

Lombardo, B., Pertusati, P. \& Borgi, S. 1993. Geology and tectonomagmatic evolution of the eastern Himalaya along the Chomolungma-Makalu transect. In: Treloar, P.J. \& SeArle, M.P. (eds) Himalayan Tectonics. Geological Society London, Special Publications, 74, 341-355.

Macfarlane, A.M. 1993. Chronology of tectonic events in the crystalline core of the Himalaya, Langtang National Park, Central Nepal. Tectonics, 12, 1004-1025.

— Hodges, K.V. \& Lux, D. 1992. A structural analysis of the Main Central Thrust zone, Langtang National Park, central Nepal Himalaya. Geological Society of America Bulletin, 104, 1389-1402.

Molnar, P. 1988. Structure and Tectonics of the Himalaya: constraints and implications of geophysical data. Annual Review of the Earth and Planetary Sciences, 12, 489-518.

Nelson, K.D. \& 27 OTHERs 1996. Partially molten middle crust beneath southern Tibet: synthesis of Project INDEPTH resuls. Science, 274, 1684-1688.

Noble, S.R. \& Searle, M.P. 1995. Age of crustal melting and leucogranite formation from $\mathrm{U}-\mathrm{Pb}$ zircon and monazite dating in the western Himalaya, Zanskar, India. Geology, 23, 1135-1138.
Odell, N.E. 1948. Geological and some other observations in the Mount Everest region. In: Tilman, H.W. (ed.) Mount Everest 1938. Cambridge University Press, 143-154.

PÊCHER, A. 1989. The metamorphism in the Central Himalaya. Journal of Metamorphic Geology, 7, 31-41.

Pognante, U. \& Benna, P. 1993. Metamorphic zonation, migmatization and leucogranites along the Everest transect of eastern Nepal and Tibet: record of an exhumation history. In: Treloar, P.J. \& Searle, M.P. (eds) Himalayan Tectonics. Geological Society, London, Special Publications, 74, 323-340.

Polino, R. 1981. Geological Map of the Upper Imja Khola, scale 1:25,000. S.E.L.C.A., Firenza, Italy.

SCHÄRER, U. 1984. The effect of initial ${ }^{230} \mathrm{Th}$ disequilibration on U-Pb ages: the Makalu case. Earth and Planetary Science Letters, 67, 191-204.

—, Xu, R.H. \& Allegre, C.J. 1986. U-(Th)-Pb systematics and ages of Himalayan leucogranites, south Tibet. Earth and Planetary Science Letters, 77, 35-48.

SEARLE, M.P. 1996. Cooling history, erosion, exhumation and kinematics of the Himalaya-Karakoram-Tibet orogenic belt. In: AN YIN \& HARRISON, T.M (eds). The Tectonic Evolution of Asia. Rubey volume. Cambridge University Press, 110-137.

— Cooper, D.J.W. \& Rex, A.J. 1988. Collision tectonics of the LadakhZanskar Himalaya. Philosophical Transactions of the Royal Society, London, A326, 117-150.

- Corfield, R., Stephenson, B. \& McCarron, J. 1997b. Structure of the North Indian continental margin in the Ladakh-Zanskar Himalayas: implications for the timing of obduction of the Spongtang ophiolite, India-Asia colllision and deformation events in the Himalaya. Geological Magazine, 134, 297-316.

—, Metcalfe, R.P., Rex, A.J. \& Norry, M.J. 1993. Field relations, petrogenesis and emplacement of the Bhagirathi leucogranite, Garhwal Himalaya. In: Treloar, P.J. \& Searle, M.P. (eds) Himalayan Tectonics. Geological Society, London, Special Publications, 74, 429-444.

- Parrish, R.R., Hodges, K.V., Hurford, A., Ayres, M.W. \& Whitehouse, M.J. 1997a. Shisha Pangma leucogranite, South Tibetan Himalaya: Field Relations, Geochemistry, Age, Origin and Emplacement. Journal of Geology, 105, 295-317.

—, Windley, B.F., Coward, M.P., Cooper, D.J.W., Rex, A.J., Rex, D.C., LI Tingdong, Xiao Xuchang, Jan, M.Q., Thakur, V.C. \& Kumar, S. 1987. The closing of Tethys and tectonics of the Himalaya. Geological Society of America Bulletin, 98, 678-701.

SwAPP, S.M. \& Hollister, L.S. 1991. Inverted metamorphism within the Tibetan slab of Bhutan: evidence for a tectonically transported heat source. Canadian Mineralogist, 29, 1019-1041.

Vannay, J.-C. \& Hodges, K.V. 1996. Tectonometamorphic evolution of the Himalayan metamorphic core between the Annapurna and Dhaulagiri, central Nepal. Journal of Metamorphic Geology, 14, 635-656.

WAGER, L.R. 1965. Injected granite sheets of the Rongbuk valley and the north face of Mt. Everest. In: D. N. Wadia commemorative volume. India Mining, Geology and Metallurgy Institute, 358-379.

WANG, Z. \& ZHEN, X. 1975. Imbricate structure in the northern slope of Jolmo Lungma and discussion on the uplift of the Himalaya. In: Scientific exploration of Jolmo Lungma. Science Publishing House, Beijing, 199-221.

Weinberg, R.F. \& Searle, M.P. in press. Volatile-assisted intrusion and Autometasomatism of leucogranites in the Khumbu Himalaya, Nepal. Journal of Geology.

Wu, C., Nelson, K.D., Wortman, G., Samson, S., Yue, Y., Li, J., Kidd, W.S.F. \& Edwards, M.A. 1998. Yadong cross-structure and South Tibetan Detachment in the east central Himalaya $\left(89^{\circ}-90^{\circ} \mathrm{E}\right)$. Tectonics, 17, 28-45.

YIN, C.H. \& Kuo, S.T. 1978. Stratigraphy of the Mount Jolmo Lungma and its north slope. Scientia Sinica, 21, 629-644. 